\title{
Deteksi Kandungan Logam Berat Timbal Pada Hati Ikan Pari (Dasyatis sp) Yang Dijual Di Pasar Gerung Kecamatan Gerung Kabupaten Lombok Barat
}

\author{
Detection of Heavy Metal in Stingray Liver (Dasyatis sp) Sold at Gerung \\ Market, Gerung District, West Lombok Regency
}

\author{
Mazrur Amzani' ${ }^{1}$ Alfiana Laili Dwi Agustin ${ }^{2 *}$, Dina Oktaviana ${ }^{3}$, Candra Dwi \\ Atma $^{4}$ \\ ${ }^{1}$ Mahasiswa, ${ }^{2}$ Dosen Divisi Kesehatan Masyarakat Veteriner, ${ }^{3}$ Dosen Divisi Produksi \\ dan Reproduksi Veteriner, ${ }^{4}$ Dosen Divisi Mikrobiologi dan Parasitologi Veteriner \\ Fakultas Kedokteran Hewan Universitas Pendidikan Mandalika \\ Jl. Pemuda No. 59A, Mataram, Nusa Tenggara Barat, Indonesia \\ *E-mail: alfiana.laili@gmail.com
}

\begin{abstract}
ABSTRAK
Logam berat timbal adalah logam berat yang manfaatnya tidak diketahui untuk organisme air. Namun, jumlah timbal diatas ambang batas dapat mengganggu kelangsungan hidup organisme akuatik dan juga manusia. Penyebab utama peningkatan kadar timbal diperairan yaitu penggunaan cat yang mengandung timbal, pengelasan kapal, dan bahan bakar yang bocor dari kapal perikanan. Penelitian ini bertujuan untuk mengetahui kandungan logam berat timbal $(\mathrm{Pb})$ yang terdeteksi pada hati ikan pari yang diperoleh dari Pasar Gerung Kecamatan Gerung Kabupaten Lombok Barat. Hati ikan pari dicuci, setelah dilakukan pencucian hati ikan pari di gerus sampai halus. Hati ikan pari kemudian ditimbang sebanyak 2-3 g, kemudian dimasukkan ke dalam tabung sampel (vassel), untuk kontrol positif ditambahkan larutan standar Pb $200 \mu \mathrm{g} / 1$ sebanyak 1 liter. Ditambakan larutan 5 ml HNO3 65\% dan $2 \mathrm{ml} \mathrm{H} 2 \mathrm{O} 2$, kemudian didestruksi menggunakan microwave. Hasil dari destruksi, sampel diuji menggunakan Inductively Coupled Plasma (ICP) dengan panjang gelombang 220,353 nm. Hasil dari penelitian menunjukkan bahwa kandungan logam berat timbal pada hati ikan pari sebesar 0,092-0,25 mg/kg yang diperoleh dari Pasar Gerung, Lombok Barat.
\end{abstract}

Kata Kunci: Ikan pari; Dasyatis sp; Timbal; Hati 


\begin{abstract}
The heavy metal is unknown use to aquatic organisms. However, the amount of lead above heavy metal can be thereshold for the survival of aquatic organisms and human. The causa of increase heavy metal in waters is using paint containing lead, ship welding, and leaking fuel from fishing boats. This study aims to determine the content of the heavy metal $(\mathrm{Pb})$ lead of stingrays liver obtained from the traditional Gerung Market, Gerung sub-district, West Lombok district. Stringray (Dasyatis $s p$ ) liver is washed, after washingg the stingray liver is crushed until smooth. Stingray liver was then weighed as much as $2-3 \mathrm{~g}$, then mashered into the sample tube (vassel), for postif control, 1 Liter standard $\mathrm{Pb} 200 \mu \mathrm{g}$ was added. Add a solution of $5 \mathrm{ml} \mathrm{HNO} 3$ and $2 \mathrm{ml}$ $\mathrm{H} 2 \mathrm{O} 2$, then digested using a microwave. The results of the digestion, the sample was tested using Inductively Coupled Plasma (ICP) with a wavelength of $220.353 \mathrm{~nm}$. The results of the study showed that the content of the heavy metal in the liver of stingrays was 0,092-0,25 mg/ $\mathrm{kg}$ which was obtained from the Traditional Gerung Market, West Lombok.
\end{abstract}

Keyword: Stingray; Dasyatis sp; Heavy metal; Liver

PENDAHULUAN

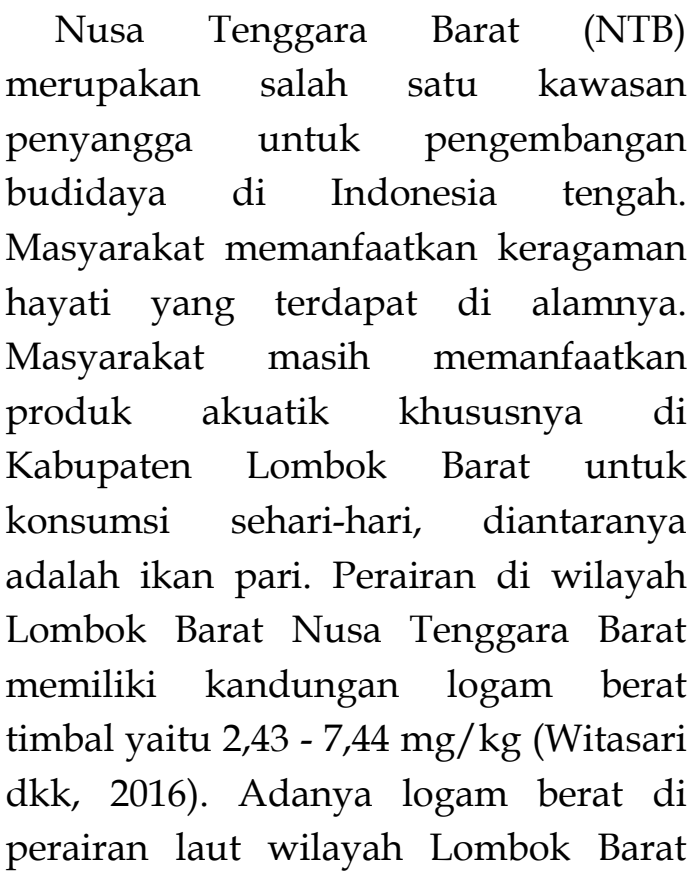

berpotensi terakumulasi pada ikan pari yang ditangkap oleh nelayan setempat.

Perairan yang tercemar oleh timbal akan berdampak negatif bagi biota laut. Logam berat timbal dapat masuk ke dalam tubuh organisme laut melalui rantai makanan, insang atau difusi permukaan kulit dan tertimbun dalam jaringan (bio akumulasi) sehingga mengakibatkan kerusakan organ dalam jaringan tubuh (Palar, 1994). Logam berat timbal dapat terakumulasi pada organ hati dan ginjal (Darmono, 2001).

Berdasarkan hasil penelitian yang dilakukan oleh Budiyanto dkk (2015) menunjukan bahwa dalam hati ikan pari dengan spesies Himantura gerrardi terdapat kandungan logam berat 
mencapai 0,020 - 0,030 $\mathrm{mg} / \mathrm{kg}$, spesies Himantura walga mencapai 0,040 - 0,182 $\mathrm{mg} / \mathrm{kg}$, spesies Himantura uarnociades mencapai 0,35 - 0,047 mg/kg, dan spesies Neotrygon kuhlii mencapai 0,060 - 0,173 mg/kg. Kandungan logam berat timbal pada ikan yang terdapat di Muara Badak Kutai Kartanegara Kalimantan Timur sebesar 0,10 - 0,60 $\mathrm{mg} / \mathrm{kg}$ (Suyatna dkk, 2017).

Logam berat merupakan salah satu bahan kimia berbahaya yang secara alami ada di lingkungan akuatik, baik dalam bentuk terlarut dalam air laut maupun terdeposisi dalam sedimen (Luoma and Rainbow, 2008). Aktivitas antropogenik dapat mempengaruhi kelimpahan logam berat (Cabon et al., 2010; Castillo et al., 2013). Salah satu pengaruh negative logam berat adalah kemampuannya untuk terakumulasi dan bersifat toksik dalam tubuh organisme (Reed et al., 2010; Lepland et al., 2010; Mohammed et al., 2012). Ikan Pari memiliki risiko mengakumulasi logam berat dalam jumlah besar karena logam berat mengalami biomagnifikasi (Chi et al, 2007; Creighton and Twinning, 2010). Jika manusia mengonsumsi organisme air yang mengandung logam berat maka akan memberikan dampak merugikan bagi kesehatan manusia seperti radang tenggorokan, nyeri kepala, dermatitis, alergi, gagal ginjal, pneumonia, dan lain sebagainya (Effendi et al., 2012). Gejala keracunan logam berat yang berupa gangguan saraf diantaranya kebutaan, koma dan kematian (Darmono, 1995).
Tingkat akumulasi logam berat pada ikan pari di Lombok barat belum banyak di ketahui, untuk mencegah dampak yang tidak diinginkan bagi konsumen maka perlu dilakukan penelitian mengenai kandungan logam berat pada ikan pari. Selain itu, logam berat pada ikan pari merupakan salah satu parameter kadar logam berat yang ada di perairan tempat hidup ikan tersebut (Pratiwi, 2020).

\section{MATERI DAN METODE}

Penelitian ini menggunakan epidemologi deskriptif dengan rancangan cross sectional study. Sampel penelitian ini diambil secara acak dari 7 penjual yang menjual ikan pari di Pasar Gerung Kecamatan Gerung Kabupaten Lombok Barat. Dalam waktu 1 hari rata-rata penjual mampu menjual sejumlah 4 ekor ikan pari. Sampel diambil $10 \%=3$ sampel dari total populasi per hari.

\begin{abstract}
Alat dan Bahan
Alat yang digunakan dalam penelitian ini adalah aluminium foil, gelas beaker $25 \mathrm{ml}$, gelas beaker $100 \mathrm{ml}$, gelas beaker $250 \mathrm{ml}$, blender / homogenizer, botol polypropylene, cawan porselen bertutup, corong plastik, desikator, gelas ukur 25 $\mathrm{ml}$, gelas ukur $50 \mathrm{ml}$, hot plate, labu takar $50 \mathrm{ml}$, labu takar $100 \mathrm{ml}$, microwave, mikro pipet, oven, pipet tetes, pipet volumetrik $10 \mathrm{ml}$, pipet volumetrik $5 \mathrm{ml}$, pipet volumetrik $1 \mathrm{ml}$,
\end{abstract}


pisau, freezer, sendok plastik, timbangan analitik, tungku pengabuan, wadah polystyrene, dan Inductively Coupled Plasma (ICP).

Bahan yang digunakan dalam penelitian ini adalah ikan pari yang diperoleh dari pedagang ikan di Pasar Gerung, Kecamatan Gerung, Kabupaten Lombok Barat. Bahan-bahan penelitian yang digunakan adalah alkohol, aqua demin, asam sitrat, aquabides, $\mathrm{HNO}_{3}$ pekat, dan HCL pekat.

\section{Waktu dan Tempat Penelitian}

Penelitian ini dilakukan pada bulan Februari 2021. Pengujian sampel dilakukan di Balai Laboratorium Kesehatan Pengujian dan Kalibrasi (BLPK) Provinsi Nusa Tenggara Barat.

\section{Prosedur Penelitian}

Pengujian Timbal

Hati ikan pari yang telah diambil dari pasar dibawa ke laboratorium, hari yang sudah diambil tersebut dicuci dengan aquadest kemudian dilakukan penggerusan. Hati yang sudah halus kemudian ditimbang sebanyak 2-3 g, hasil penimbangan hati ikan pari dimasukkan ke dalam tabung sampel (vassel). Kontrol positif dibuat dengan menambahkan $\mathrm{Pb} 200 \mu \mathrm{g} / 1$ sebanyak 1 $\mathrm{ml}$, kemudian semua tabung ditambah dengan larutan HNO3 65\% sebanyak 5 $\mathrm{ml}$ dan $\mathrm{H} 2 \mathrm{O} 2$ sebanyak $2 \mathrm{ml}$ secara berurutan. Setelah semua bahan dimasukkan, dilakukan destruksi dengan mengatur program microwave. Hasil destruksi dipindah ke labu takar ukuran $25 \mathrm{ml}$ dan ditambahkan larutan matrix modifier sampai batas dengan ionisasi (BSN, 2011).

Analisis Timbal (Pb)

Analisi timbal terdiri atas beberapa tahap, antara lain tahap destruksi basah dan tahap pengukuran konsentrasi timbal menggunakan Inductively Coupled Plasma (ICP). Panjang gelombang yang digunakan dalam menganalisis logam berat timbal 220,353 mm (BNI, 2011).

Konsentrasi logam berat dihitung menggunakan rumus :

$$
\text { KonsentrasiPb } \frac{(\mathrm{D}-\mathrm{E}) \mathrm{xFpxV}}{\mathrm{W}}
$$

Dimana D merupakan konsentrasi dari hasil pembacaan ICP, E adalah konsentrasi blanko dari hasil pembacaan ICP, Fp adalah faktor pengenceran, $\mathrm{V}$ adalah volume akhir larutan yang disiapkan dan $\mathrm{W}$ adalah berat sampel. 


\section{HASIL}

Hasil Pemeriksaan sampel hati ikan pari menunjukkan bahwa kandungan logam berat berkisar antara 0,092 - 0,25 (Tabel 1)

Tabel 1. Kandungan Logam Berat Timbal pada Ikan Pari

\begin{tabular}{cc}
\hline Sampel & $\begin{array}{c}\text { Kadar timbal }(\mathrm{Pb}) \\
\text { pada ikan pari } \\
(\mathrm{mg} / \mathrm{kg})\end{array}$ \\
\hline Sampel 1 & 0,25 \\
Sampel 2 & 0,092 \\
Sampel 3 & 0,099 \\
\hline
\end{tabular}

Berdasarkan hasil pemeriksaan kandungan logam berat pada hati ikan pari yang dijual di Pasar Gerung, Kecamatan Gerung, Kabupaten Lombok Barat mengandung logam berat timbal berkisar antara 0,092-0,25 $\mathrm{mg} / \mathrm{kg}$ dengan tingkat kepercayaan 90,4\%.

\section{PEMBAHASAN}

Ikan pari yang diperoleh dari Pasar Gerung Kecamatan Gerung Kabupaten Lombok Barat masing-masing dengan berat P1 1.898 g, P2 $1.786 \mathrm{~g}$ dan P3 1.868 g. Banyak faktor yang mempengaruhi kemampuan ikan dalam mengakumulasi logam berat. Ukuran tubuh seperti panjang dan berat, jenis kelamin, umur, tingkah laku dan kemampuan ekskresi akan memberikan variasi akumulasi logam berat dalam tubuh ikan, bahkan dalam spesies yang sama (Luoma and Rainbow, 2008; Ruelas-Inzunza et al., 2013).

Rendahnya konsentrasi logam berat pada hati ikan pari merupakan salah satu indikasi rendahnya kadar logam berat di perairan tempat hidup ikan tersebut. Menurut Witasari dkk (2016) kandungan logam berat di perairan laut wilayah Lombok Barat sebesar 2,43-7,44 $\mathrm{mg} / \mathrm{kg}$ dimana adanya kandungan logam berat dalam air laut tersebut terbukti terakumulasi dalam hati ikan pari.

Timbal yang melebihi batas maksimal yang sudah ditetapkan oleh BPOM dapat mengganggu kelangsungan hidup organisme akuatik dan juga manusia (Yolanda dkk, 2017). Logam berat pada tubuh ikan dapat terjadi karena adanya kontak antara medium yang mengandung toksik dengan ikan, pemindahan zat kimia dari lingkungan air ke dalam atau permukaan tubuh ikan, logam berat dapat masuk melalui insang. Logam berat yang masuk ke dalam tubuh ikan akan terakumulasi di dalam organ hati dan ginjal (Yulaipi, 2013).

Logam berat konsentrasi rendah dibutuhkan oleh organisme hidup untuk pertumbuhan dan perkembangan, namun apabila kadar meningkat, maka logam akan berubah menjadi racun (Puspasari, 2006). 
Terdapat 2 mekanisme logam berat masuk ke dalam tubuh mahluk hidup, yaitu secara langsung dan tidak langsung. Mekanisme langsung terjadi saat ikan melakukan respirasi melalui insang ke dalam tubuh. Cara lain logam berat dapat masuk ke dalam tubuh organisme hidup adalah melalui rantai makanan. Proses makan-memakan, terjadi transfer bahan dan energy dari organisme yang dimangsa ke organisme pemangsa (Puspasari, 2006).

Ikan yang dimangsa mempunyai kemampuan dalam menyerap dan mengakumulasi logam berat dalam sel. Apabila ikan-ikan kecil dimangsa oleh ikan predator, maka akan terjadi transfer logam berat tersebut ke dalam tubuh predator tersebut. Transfer logam berat akan terus berlangsung sampai dengan ketingkat trofik tertinggi. Semakin tinggi tingkatan trofik, maka akumulasi logam berat dalam tubuh akan semakin banyak. Kandungan logam di lingkungan hidup ikan pada taraf tertentu akan sebanding dengan kandungan logam dalam sel organisme yang hidup di lingkungan tersebut (Puspasari, 2006).

Ikan dapat mengekresikan toksin di dalam tubuhnya melalui organ dalam seperti hati. Hati sebagai organ ekskresi mendapat tekanan yang cukup besar dalam detoksikasi logam berat. Beberapa jenis organisme, hati merupakan salah satu organ yang paling banyak mengakumulasi logam berat sebelum logam berat tersebut berhasil dieksresikan (Luoma and Rainbow, 2008).

Konsentrasi logam berat tertinggi dalam hepar ikan yaitu sebesar 2,05 $\mathrm{mg} / \mathrm{kg}$, yang berarti bahwa akumulasi $\mathrm{Pb}$ dalam hepar lebih cepat dibandingkan dengan daging. Keadaan tersebut dikarenakan hati merupakan organ detoksifikasi yang dapat menetralkan racun yang masuk (Nelson, 2016). Akumulasi logam yang tertinggi biasanya terdapat dalam hati. Hati merupakan organ yang berfungsi untuk menghilangkan zat toksik yang masuk ke dalam tubuh, sehingga organ ini sangat potensial menderita keracunan lebih dahulu sebelum organ lain (Robbins and Kumar, 1995). Hasil penelitian ini menunjukan bahwa pada ikan pari yang dijual di pasar Gerung, Kecamatan Gerung Kabupaten Lombok Barat kurang dari Kadar maksimal logam berat pada ikan (BPOM, 2018). Kadar maksimal logam berat ikan menurut BPOM sebesar $0.40 \mathrm{mg} / \mathrm{kg}$ sehingga dapat dikatakan hati ikan tersebut masih dapat dikonsumsi.

Ekskresi logam berat timbal dalam tubuh secara keseluruhan terjadi dalam waktu paruh sekitar 28 hari. Dari darah dan tempat deposit, Timbal (Pb) kemudian diekskresikan melalui urin dan feses tetapi tidak semua logam berat dapat diekskresikan dari dalam tubuh (Riyadina, 1997).

\section{KESIMPULAN}


Berdasarkan hasil penelitian ini dapat disimpulkan bahwa logam berat Timbal terdeteksi di hati ikan pari (Dasyatis $\mathrm{sp}$ ) dengan kadar logam berat 0,092-0.25 $\mathrm{mg} / \mathrm{kg}$ yang diperoleh dari Pasar Gerung Kecamatan Gerung Kabupaten Lombok Barat.

Perlu dilakukan penelitian lebih lanjut mengenai deteksi logam berat lainnya dan perlu juga dilakukan penelitian lebih lanjut mengenai deteksi logam berat yang berada pada kulit dan insang ikan pari (Dasyatis sp).

\section{UCAPAN TERIMAKASIH}

Terimakasih kepada Depertemen Kimia Balai Laboratorium Kesehatan Pengujian dan Kalibrasi, yang telah membantu dan memberikan dukungan selama penelitian dan terimakasih kepada penjual ikan pari yang berada di Pasar Gerung Kecamatan Gerung Kabupaten Lombok Barat yang telah membantu kelancaran penelitian ini.

\section{DAFTAR PUSTAKA}

Badan Pengawasan Obat Dan Makanan (BPOM). 2018. Batas Maksimum Cemaran Logam Berat Dalam Pangan Olahan.

Badan Standardisasi Nasional (BSN). 2011. Penentuan Kadar Logam Berat Timbal (Pb) Dan Kadmium (Cd) Pada Produk Perikanan. Standar Nasional Indonesia (SNI). SNI 2354 (5), 1-6.
Budiyanto, F., Lestari dan Fahmi., 2015.

Bioakumulasi Merkuri Dalam Daging Dan Hati Ikan Pari Dari Teluk Jakarta. Oldi, Vol 41(2): 121244

Cabon, J. Y., Giamarchi, P., \& Le Floch, S. (2010). A Study Of Marine Pollution Caused By The Release Of Metals Into Seawater Following Acid Spills. Marine Pollution Bulletin, 60(7), 998-1004.

Castillo, M. A., Trujillo, I. S., Alonso, E. V., De Torres, A. G., \&Pavón, J. C. (2013). Bioavailability Of Heavy Metals In Water And Sediments From A Typical Mediterranean Bay (Málaga Bay, Region Of Andalucía, Southern Spain). Marine Pollution Bulletin, 76(1-2), 427-434.

Chi, Q. Q., Zhu, G. W., \& Langdon, A. (2007). Bioaccumulation Of Heavy Metals In Fishes From Taihu Lake, China. Journal Of Environmental Sciences, 19(12), 1500-1504.

Creighton, N., \& Twining, J. (2010). Bioaccumulation From Food And Water Of Cadmium, Selenium And Zinc In An Estuarine Fish, Ambassis Jacksoniensis. Marine Pollution Bulletin, 60(10), 1815-1821.

Darmono, 1995. Logam Dalam Sistem Biologi Makhluk Hidup. Universitas Indonesia Press, Jakarta

Darmono, 2001. Lingkungan Hidup Dan Pencemaran. Universitas Indonesia Press, Jakarta

Effendi, F., Tresnaningsih, E., Sulistomo, A.W., Wibowo, S., Hudoyo, K.S. (2012). Penyakit Akibat 
Kerja Karena Pajanan Logam Berat. Jakarta: Direktorat Bina Kesehatan Kerja Dan Olahraga Kementerian Kesehatan Republik Indonesia.

Lepland, A., Andersen, T. J., Lepland, A., Arp, H. P. H., Alve, E., Breedveld, G. D., \&Rindby, A. (2010). Sedimentation And Chronology Of Heavy Metal Pollution In Oslo Harbor, Norway. Marine Pollution Bulletin, 60(9), 1512-1522.

Luoma, S. N., \& Rainbow, P. S. (2008). Metal Contamination In Aquatic Environments: Science And Lateral Management. Cambridge University Press.

Mohammed, A., May, T., Echols, K., Walther, M., Manoo, A., Maraj, D., \&Orazio, C. (2012). Metals In Sediments And Fish From Sea Lots And Point Lisas Harbors, Trinidad And Tobago. Marine Pollution Bulletin, 64(1), 169-173.

Nelson, J. S., Grande, T. C., \& Wilson, M. V. (2016). Fishes Of The World. John Wiley \& Sons.

Palar, H. (1994). Pencemaran Dan ToksikologiLogamBerat.

Pratiwi, D. Y. (2020). Dampak Pencemaran Logam Berat Terhadap Sumber Daya Perikanan Dan Kesehatan Manusia. Jurnal Akuatek, 1(1), 59-65.

Puspasari, R. (2017). Logam Dalam Ekosistem Perairan. Bawal Widya Riset Perikanan Tangkap, 1(2), 43-47. Puspitasari, R., \&Natsir, S. M. (Eds.). (2016). Kualitas Lingkungan Untuk
Menunjang Budi Daya Biota Laut Di Perairan Lombok Barat. LIPI Press.

Reed, L. A., Pennington, P. L., \& Wirth, E. (2010). A Survey Of Trace Element Distribution In Tissues Of Stone Crabs (Menippe Mercenaria) From South Carolina Coastal Waters. Marine Pollution Bulletin, 60(12), 2297-2302.

Riyadina, W. (1997). Pengaruh Pencemaran Plumbum Terhadap Kesehatan. Media Litbangkes. BalitbangDep.Kes. RI.Jakarta

Robins, S. L Dan V. Kumar. (1995). Patologi I (Diterjemahkan Oleh Staff Pengajar Patologi Anatomi FK Universitas Airlangga). EGC. Jakarta Ruelas-Inzunza, J., Escobar-Sánchez, O., Patrón-Gómez, J., Moreno-Sanchez, X. G., Murillo-Olmeda, A., Spanopoulos-Hernández, M., \&Corro-Espinosa, D. (2013). Mercury In Muscle And Liver Of Ten Ray Species From Northwest Mexico. Marine Pollution Bulletin, 77(1-2), 434-436.

Suyatna, I., Adnan, A., Syahrir, M., Ghitarina, G., Abdunnur, A., \& Saleh, S. (2017). Heavy Metal Levels In Water And Fish Samples From Coastal Waters Of Mahakam Delta, Kutai Kartanegara District, East Kalimantan, Indonesia. Aquaculture, Aquarium, Conservation \& Legislation, 10(5), 1319-1329.

Witasari, Y., Lestari., Prayitno., H. B., Budiyanto. F., Puspitasari. R., Purbonegoro. T., Rostitasari. R., Kadi. A., Noerdjito D. R., 
Panggabean. M. G. L., dan Autoso. 2016. Kualitas Lingkungan untuk Menunjang Budi Daya Biota Laut di Perairan Lombok Barat. Lembaga Ilmu Pengetahuan Indonesia.

Yolanda, S., Rosmaidar, Nazaruddin, Armansyah, T., Balqis, U., And Fahrima, Y. 2017. Pengaruh Paparan Timbal $(\mathrm{Pb})$ Terhadap Histopatologis
Insang Ikan Nila (Oreochromis Nilloticus). Jurnal Ilmiah Mahasiswa Veteriner, 1 (4), 736-741.

Yulaipi, S., \& Aunurohim, A. 2013. Bioakumulasi Logam Berat Timbal $(\mathrm{Pb})$ Dan Hubungannya Dengan Laju Pertumbuhan Ikan Mujair (Oreochromis Mossambicus). Jurnal Sains Dan Seni ITS, 2(2), E166-E170. 